\title{
Recombinant Production of Horseradish Peroxidase Conjugates with Fab Antibodies in Pichia pastoris for Analytical Applications
}

\author{
O.V. Koliasnikov ${ }^{1,2 \#, ~ V . G . ~ G r i g o r e n k o ~}{ }^{2 *}$, A.M. Egorov², S. Lange ${ }^{3}$, R.D. Schmid ${ }^{3}$ \\ ${ }^{1}$ Kolmogorov Advanced Education and Science Center, Lomonosov Moscow State University \\ 2Department of Chemistry, Lomonosov Moscow State University \\ ${ }^{3}$ Institute of Technical Biochemistry, University of Stuttgart \\ *E-mail: vitaly@immunotek.ru \\ \# The authors provided equivalent contributions to the study. \\ Received 05.05.2011 \\ Copyright () 2011 Park-media, Ltd. This is an open access article distributed under the Creative Commons Attribution License, which permits \\ unrestricted use, distribution, and reproduction in any medium, provided the original work is properly cited.
}

\begin{abstract}
Recombinant immunoconjugates of marker enzymes with antigens or antibodies present considerably more advantages than those obtained by conventional methods of chemical synthesis; i.e. they are homogeneous, have a strictly determined stoichiometry, and retain the functional activity of both a marker protein and an antigen/antibody. Based on the pPICZ $\alpha$ B shuttle vector, we first managed to obtain a recombinant conjugate of key marker enzyme horseradish peroxidase (HRP) with $\mathrm{Fab}$ fragments of antibodies against atrazine. The resulting genetic construction allows us to switch to any other antibody sequence, via the simple re-cloning of variable parts and an additional reporter enzyme. Conjugates were successfully produced in the Pichia pastoris methylotrophic yeast expression system. The target activity of the conjugates (both enzymatic and antigen-binding) has been demonstrated by ELISA method.

KEYWORDS horseradish peroxidase; antibodies; recombinant conjugates; Pichia pastoris expression.

ABBREVIATIONS HRP - horseradish peroxidase; ELISA - enzyme-linked immunosorbent assay; BSA - bovine serum albumin; PCR - polymerase chain reaction; TMB - 3,3',5,5'-tetramethylbenzidine; ABTS - 2,2'-azinobis(3ethylbenzothiazoline-6-sulphonic acid).
\end{abstract}

\section{INTRODUCTION}

Enzyme immunoassays for the detection and quantitative analysis of various substances are based on coupling of marker enzymes such as horseradish peroxidase (HRP, EC 1.11.1.7]) with antigens or antibodies. However, all major approaches used for the chemical conjugation of proteins and haptens result in the partial inactivation of the enzyme and conjugate heterogeneity, which affects the specificity and sensitivity of the ELISA. Genetic engineering can be used to obtain recombinant conjugates of proteins with antigens or antibodies. Such conjugates present a number of advantages; firstly, they have a homogenous composition, secondly, they possess $1: 1$ stoichiometry, thirdly they retain the functional activities of both the marker protein and that of the antigen/ antibody, in addition to the reproducibility and the fact that they are relatively simple to produce. Recombinant conjugates of antibodies with alkaline phosphatase [1-3], luciferase [4], and peroxidase Arthromyces ramosus [5] were obtained earlier.
The recombinant conjugate of $\mathrm{HRP}$ with the earlier obtained fatty-acid-binding protein (FABP) [6] was expressed in Escherichia coli cells and used as an immunotracer when performing immunoenzyme assay aimed at the early diagnosis of myocardial infarction.

The functional expression of the recombinant conjugate of HRP and antibody fragments in E. coli is associated with a number of difficulties, since there is no post-translational glycosylation of proteins in E. coli cells, resulting in low solubility and aggregation of the expressed/obtained protein. This problem can be solved by replacing the expression system. For instance, it has been shown that methylotrophic yeast Pichia pastoris is a more suitable organism/system for antibody expression than $E$. coli cells [7, 8].

HRP [9] and antibody fragments [10] were successfully expressed individually in P. pastoris cells, both in the single-stranded form scFv $[11,12]$ and in a Fab form [13]. Moreover, certain immunoconjugates have 
also been created using this expression system [14-16]. It has been demonstrated that gene expression in the $P$. pastoris system in the secreted form considerably simplifies the scaling of the process for biochemical applications [17].

The recent advance in the functional expression of HRP and antibodies in secreted form paves the way for the construction of recombinant $\mathrm{HRP}$-antibody conjugates to be used in immunoassays. Firstly, we obtained recombinant conjugates of HRP and Fab-fragments of antibodies against atrazine, in order to study the opportunities provided by this approach. In these chimeric proteins, the peroxidase part is combined with the $\mathrm{N}$ - and C-terminal parts of the heavy chain of an antibody via a short linker sequence. The universal vectors for the expression of conjugates of HRP and variable chains of Fab fragments of antibodies were obtained (a simple replacement of the variable part of a heavy and light chain of any other antibody by re-cloning at the PstI/BstEII and BamHI/XhoI sites, respectively) in the secreted form in P. pastoris cells. A functionally active $\mathrm{HRP}-\mathrm{Fab}$ (atrazine) conjugate was obtained, possessing antigen-binding properties that are similar to those of monoclonal antibodies, which has been attested by single-stage competitive immunoassay of atrazine $\left(\mathrm{IC}_{50}\right.$ $\sim 3 \mathrm{ng} / \mathrm{ml}$ ).

\section{EXPERIMENTAL}

\section{Reagents}

The reagents were purchased from the companies Sigma, Fluka, and Difco and used without further purification. Protein electrophoresis (SDS-PAGE) was performed according to the standard procedure, using a low molecular weight protein kit (LMW, Bio-Rad) as the molecular weight standards. The preparative work with DNA was performed using a QIA prep Spin Miniprep Kit and a QIAquick Gel extraction Kit (Qiagen, Germany). Enzymes for DNA restriction and modification were purchased from New England Biolabs, Boehringer-Mannheim, GIBCO-BRL-Life technologies, and MBI. Oligonucleotides for sequencing and PCR were purchased from ARK Scientific, MWG Biotech, or Interactiva (Germany).

\section{Data processing and presentation}

The gene engineering part of the study was planned using CloneManager software (Scientific \& Educational Software, Cary, United States). The spatial structures of immunoconjugates were simulated and visualized on the InsightII (BioSym Inc., United States) software package (BioSym Inc., United States) on an SGI R4400 operating station. The experimental data were prepared for publication using software from the OpenOf- fice.org (www.openoffice.org) and GIMP (GNU Image Manipulation Program) packages.

Microorganisms, media, plasmids, and oligonucleotides

E. coli strain DH5 $\alpha$ was used for genetic manipulations, and E. coli strain BL21(DE3) pLysS (Novagen) was used for intermediate production of the protein. The cells were cultured in an LB medium (1\% yeast extract, $1 \%$ Peptone, $0.5 \% \mathrm{NaCl}$ ) supplemented with $25 \mathrm{mg} / \mathrm{l}$ of $\mathrm{Ze}-$ ocin (Invitrogen).

Preparing competent cells. E. coli cells were grown overnight in $50 \mathrm{ml}$ of the $\mathrm{LB}$ medium until $\mathrm{OD}_{600}$ was $0.4-0.6$ and were isolated from the culture medium by centrifugation $\left(3500 \mathrm{rpm}, 4^{\circ} \mathrm{C}\right.$ ) for $10 \mathrm{~min}$. The cell precipitate/pellet was re-suspended in a TSS buffer (buffer based on a LBS medium containing $10 \mathrm{~g}$ of PEG$6000,5 \mathrm{ml}$ of DMSO, and $0.6 \mathrm{~g}$ of $\mathrm{MgCl}_{2}$ in $100 \mathrm{ml} ; \mathrm{pH}$ $6.5)$ and then kept on ice for $1 \mathrm{~h}$, aliquoted $(200 \mu \mathrm{l})$, and quickly frozen at $-80^{\circ} \mathrm{C}$.

Recombinant antibodies and their conjugates with HRP were expressed using $P$. pastoris X33 (Invitrogen) and shuttle vector pPICZ $\alpha \mathrm{B}$ (Invitrogen) for cloning.

The NotI site was removed using forward and reverse primers (Table). A three-stage PCR was used (primers listed in the Table), in order to incorporate the $H R P$ gene behind the gene of the heavy antibody chain and to remove the restriction sites BspCI, ApaI, PstI, BstEII, BglII, XhoI, BamHI, SacI, and PvuI.

\section{DNA modification and cell transformation}

Manipulations with DNA included the standard procedures [18]. E. coli cells were transformed via the addition of plasmids or a ligation mixture to the unfrozen competent cells. $P$. pastoris cells were also transformed by plasmids preliminarily linearized at the PmeI site via electroporation.

\section{$P$. pastoris cultivation and secretion}

of the recombinant conjugate

$P$. pastoris cells were cultivated in a YPD medium (1\% yeast extract, $2 \%$ Peptone, $2 \% \mathrm{D}$-glucose). The target protein was synthesized in the glucose-free YP medium, using $0.5 \mathrm{vol} \%$ methanol as an inducing agent. The YPDS medium (YPD containing $1 \mathrm{M}$ sorbitol) was used for transformation of P. pastoris cells. The solid medium contained 1.5\% of Bacto Agar. The transformants were grown in the YPDS medium at $30^{\circ} \mathrm{C}$ under stirring $(200 \mathrm{rpm})$ until $\mathrm{OD}_{600}=15$ units was obtained. The cells were centrifuged at $3,000 \mathrm{~g}$ and $4^{\circ} \mathrm{C}$, washed with YP medium, and $\mathrm{OD}_{600}$ was brought to 1 . The induction was performed for $96 \mathrm{~h}$ by adding $0.5 \mathrm{vol} \%$ metha- 
nol every $24 \mathrm{~h}$. The supernatant was concentrated via membrane ultrafiltration (Amicon, $10 \mathrm{kDa}$ ).

\section{Synthesis of bovine serum albumin}

(BSA) conjugated with atrazine

The mixture of $1 \mathrm{mg}$ of atrazine derivative (4-chloro6-(isopropylamino)-1,3,5-triazine-2-(6-amino-caproic acid)) $(\sim 3.2 \mu \mathrm{mol}), 1.7 \mathrm{mg}$ of N-hydroxysuccinimide ( $15 \mu \mathrm{mol}), 6.6 \mathrm{mg}$ of $\mathrm{N}, \mathrm{N}^{\prime}$-dicyclohexylcarbodiimide $(\sim 30 \mu \mathrm{mol})$ in $130 \mu \mathrm{l}$ of 1,4-dioxane was stirred for $8 \mathrm{~h}$ at room temperature. The precipitate was isolated by centrifuging on a desktop centrifuge (12,000 rpm, $30 \mathrm{~s})$. The supernatant was added dropwise to the BSA solution $(2 \mathrm{mg})$ in $3 \mathrm{ml}$ of $0.13 \mathrm{M} \mathrm{NaHCO}$. The reaction mixture was left in a dark place for $3 \mathrm{~h}$. The reaction product was applied to a PD-10 column that was preliminarily balanced with a phosphate-buffered saline (PBS), $\mathrm{pH} 7.5$. A total of 16 fractions ( $0.5 \mathrm{ml}$ each) were collected and analyzed spectrophotometrically (at 220 and $260 \mathrm{~nm}$ ). The fractions with the highest $\mathrm{OD}_{220 / 260} \mathrm{ra}-$ tio were combined to be used in further experiments.

\section{Determination of activity of the}

recombinant conjugate by ELISA

ELISA was performed overnight using plates ("NUNC" MAXI-SORP) with the preliminarily sorbed BSA-atrazine $(1: 100$ dilution) conjugate or $\mathrm{BSA}(10 \mu \mathrm{g} / \mathrm{ml})$ in a $10 \mathrm{mM}$ carbonate buffer, $\mathrm{pH} 9.0$, at $4^{\circ} \mathrm{C}$. The samples of supernatant of a $P$. pastoris culture medium were successively diluted in PBS, added into the plate wells, and incubated at $37^{\circ} \mathrm{C}$ for $1 \mathrm{~h}$. Then, the plate was washed thrice with PBS containing $0.1 \%$ of Tween-20 (PBS-T), and $50 \mu \mathrm{l}$ of a TMB substrate mixture was added $\left(0.6 \mathrm{mg} / \mathrm{ml}\right.$ TMB and $8 \mathrm{mM} \mathrm{H}_{2} \mathrm{O}_{2}$ in $0.1 \mathrm{M}$ acetate buffer, $\mathrm{pH} 5$ ). The reaction was stopped by adding $50 \mu \mathrm{l}$ of $2 \mathrm{M} \mathrm{H}_{2} \mathrm{SO}_{4}$; the optical density was measured at $450 \mathrm{~nm}$.

\section{Competitive ELISA for determining atrazine}

$150 \mu \mathrm{l}$ of the calibration sample $(0.1,1.0,10,20,50,100$, $500 \mathrm{ng} / \mathrm{ml}$ of atrazine in PBS-T) and $40 \mu \mathrm{l}$ of a recombinant conjugate solution were placed into plate wells with the preliminarily sorbed BSA-atrazine conjugate and incubated at $37^{\circ} \mathrm{C}$ for $1 \mathrm{~h}$. The plate was washed three times with PBS-T, and $50 \mu \mathrm{l}$ of the TMB substrate mixture was added into each well. The reaction was stopped by adding $50 \mu \mathrm{l}$ of $2 \mathrm{M} \mathrm{H}_{2} \mathrm{SO}_{4}$; the optical density was measured at $450 \mathrm{~nm}$.

\section{RESULTS AND DISCUSSION}

Recombinant conjugates are chimeric proteins combining the structural components of both marker enzymes and an antigen/antibody. The use of modern approaches has almost solved the problem of obtaining such recombinant enzymes as alkaline phosphatase, $\beta$-galactosidase, luciferase, and horseradish peroxidase that are used as markers in the ELISA methods. However, the production of recombinant conjugates is an appreciably complicated task, since it remains thus far impossible to reliably predict the structure of the desired conjugate; hence, loss of the functional activity of both the marker enzyme and antigen is possible, due to the incorrect folding of two components.

Recombinant conjugates comprising bacterial enzymes ( $\beta$-galactosidase and alkaline phosphatase) that can be easily expressed in soluble form in $E$. coli cells, as well as some other enzymes, were earlier obtained. The major problem associated with the use of $\beta$-galactosidase and alkaline phosphatase within conjugates is their tetrameric and dimeric structures, respectively, which results in a considerable increase in conjugate affinity in comparison with a free antibody. This phenomenon is particularly undesirable when designing ELISA competitive schemes. Meanwhile, horseradish peroxidase, one of the marker enzymes that have been most widely used in ELISA, is expressed in $E$. coli cells only in the form of inclusion bodies, which until recently has impeded the obtaining of an active enzyme.

The recent advance in the heterologous expression of antibody genes in the cells of methylotrophic yeast $P$. pastoris offers great opportunities for using this system for the synthesis of the conjugates of horseradish conjugates with antibodies in the secreted soluble and functionally active forms.

Designing the expression vector to obtain a recombinant conjugate of HRP with a Fab fragment of antibodies in $P$. pastoris

The expression system for obtaining recombinant conjugates of HRP and Fab fragments of antibodies was elaborated on the basis of the $\mathrm{pPICZ} \alpha \mathrm{B}$ vector. The genetic construction was placed under the control of the AOX promoter containing the PmeI site for the subsequent linearization and recombination into the yeast genome. The vector also contains the signal sequence of $\alpha$-factor, which is necessary for the directed secretion of recombinant protein into the culture medium. Gene sh ble provides zeocin resistance of both E. coli and $P$. pastoris cell types. The possibility of introducing a hexahistidine sequence at the $\mathrm{C}$-terminus of the recombinant protein is provided to simplify the procedures of extraction and purification of the product.

We used the plasmids earlier obtained (pPIC-VCL and pPIC-VCH [19] containing the corresponding fragments of variable regions of the light and heavy chains of K4E7 monoclonal antibody against atrazine [20], respectively) as the starting material (Fig. 1). Both these 
Fig. 1. Cloning scheme for construction of pPIC Fab plasmid.
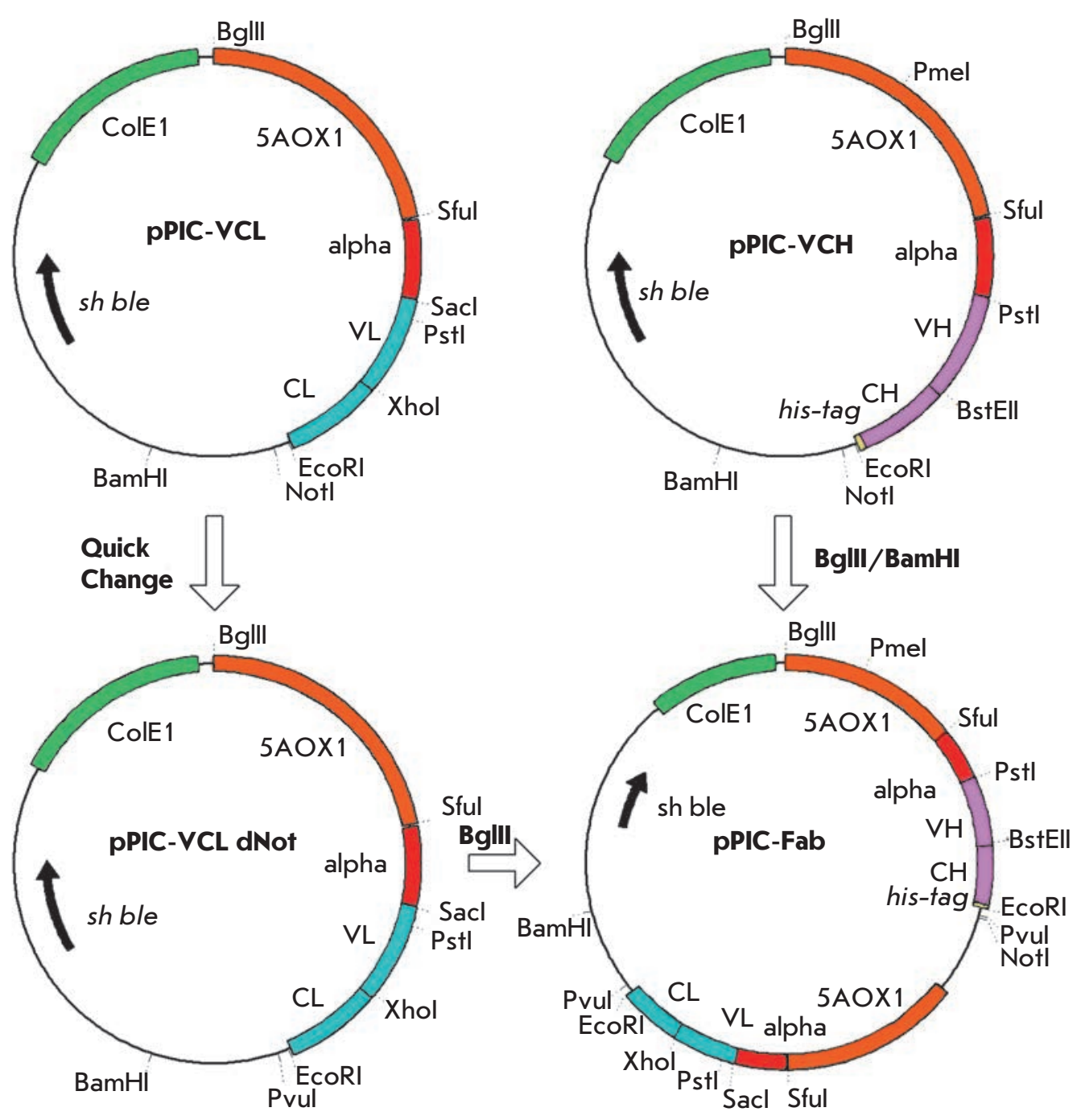

vectors contained the NotI site behind the cloned gene.

To design the universal construction, we planned to leave only one NotI site in the vector behind the gene of the antibody heavy chain. PCR (the QuickChange mode [21]) using a special primer pair (Table) was employed to remove the NotI site from the pPIC-VCL plasmid. The vector obtained by this procedure is known as pPIC-VCL dNot. Then, the BglII/BamHI fragment of the pPIC-VCH plasmid containing the heavy-chain gene was cloned at the BglII site of plasmid pPIC-VCL dNot prior to the light chain gene. The expression vector pPIC-Fab was used. The cloning scheme is given in Fig. 1.

The universal pPIC-Fab gene obtained contains SacI/XhoI and PstI/BstEII site pairs for simple cloning of the genes of the heavy and light chains, encodes the C-terminal hexahistidine fragment for simplifying the purification of the target protein using metal chelate chromatography, and the NotI site for cloning the marker protein (such as HRP, green fluorescent protein (EGFP), luciferase, etc.) at the C-terminus of the heavy chain of the antibody.

A vector for the expression of the recombinant conjugate of peroxidase with Fab fragments of antibodies was designed simultaneously. For the simplicity of cloning, restriction sites PstI, BstEII, BglII, XhoI, SacI, PvuI, ApaI, BamHI and BspCI were removed using the primers listed earlier (Table) from the initial HRP gene [22] that was preliminarily cloned in the corresponding pPIC vector. Either before the $H R P$ gene or behind it the fragments of antibody genes were simultaneously cloned. Thus, three-stage PCR was used to obtain two genetic constructions in which the HRP gene was linked with the sequence encoding the $\mathrm{N}$-terminal region of the variable part of the heavy Fab chain or the C-terminal region of the constant part of the heavy chain via a short linker sequence $\left(\mathrm{Gly}_{4} \mathrm{Ser}\right)_{3}$ (Fig. 2). It should be mentioned that in order to avoid the formation of 
Forward (F) and reversed (R) primers used for generation of genetic constructs with PCR. The introduced mutations are indicated in bold and underlined in primer sequences

\begin{tabular}{|c|c|c|c|}
\hline Target gene & Restriction site destroyed & & Primer sequence* \\
\hline $\mathrm{HRP}$ & NotI & $\mathrm{R}$ & 5'-CGATCGAGCC GCGATGGCCG CCAGC-3' \\
\hline $\mathrm{HRP}$ & NotI & $\mathrm{F}$ & 5'-GCTGGCGGCC ATCGCGGCTC GATCG-3' \\
\hline Fab VCH & & $\mathrm{R}$ & $5^{\prime}$-AGGCACAGCT ATAGGTACG-3' \\
\hline $\mathrm{Fab} \mathrm{VCH}$ & & $\mathrm{F}$ & 5'-TGAGAACCTC CACCGCCGCA GTCGCGCGGT ACG-3' \\
\hline HRP & & $\mathrm{R}$ & 5'-GCGGCGGTGG AGGTTCTCAG TTAACGCCGA CTTTCTACG-3' \\
\hline HRP & PstI, BspCI & $\mathrm{R}$ & 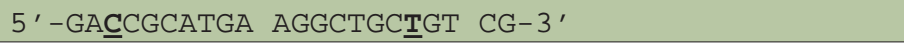 \\
\hline HRP & PstI, BspCI & $\mathrm{F}$ & 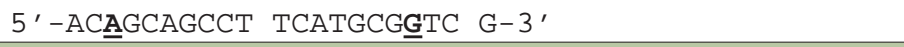 \\
\hline HRP & BstEII, ApaI & $\mathrm{R}$ & 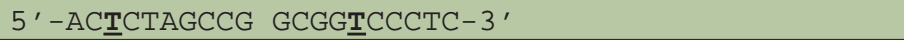 \\
\hline HRP & BstEII, ApaI & $\mathrm{F}$ & $5^{\prime}-$ GGACCGCCGG CTAGAGTGAC-3' \\
\hline HRP & XhoI & $\mathrm{R}$ & 5'-GAACCG $\underline{T} T C G$ AGTGATCTAG-3' \\
\hline HRP & XhoI & $\mathrm{F}$ & $5^{\prime}$-AGATCACTCG AACGGTTCAG-3' \\
\hline HRP & SacI & $\mathrm{R}$ & 5'-GATCAGGAGC TㅌTCTCATC-3' \\
\hline HRP & SacI & $\mathrm{F}$ & 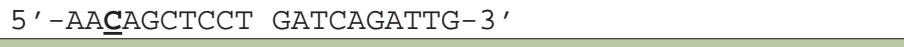 \\
\hline Fab VCL & NotI & $\mathrm{R}$ & $5^{\prime}$-ATCGGTACCT CGATCGAGCC GCGATGG-3' \\
\hline Fab VCL & NotI & $\mathrm{F}$ & $5^{\prime}$-TGAAGTGGTA CGGCGATGC-3' \\
\hline
\end{tabular}

"The nucleotide sequence regions that were changed are highlighted.
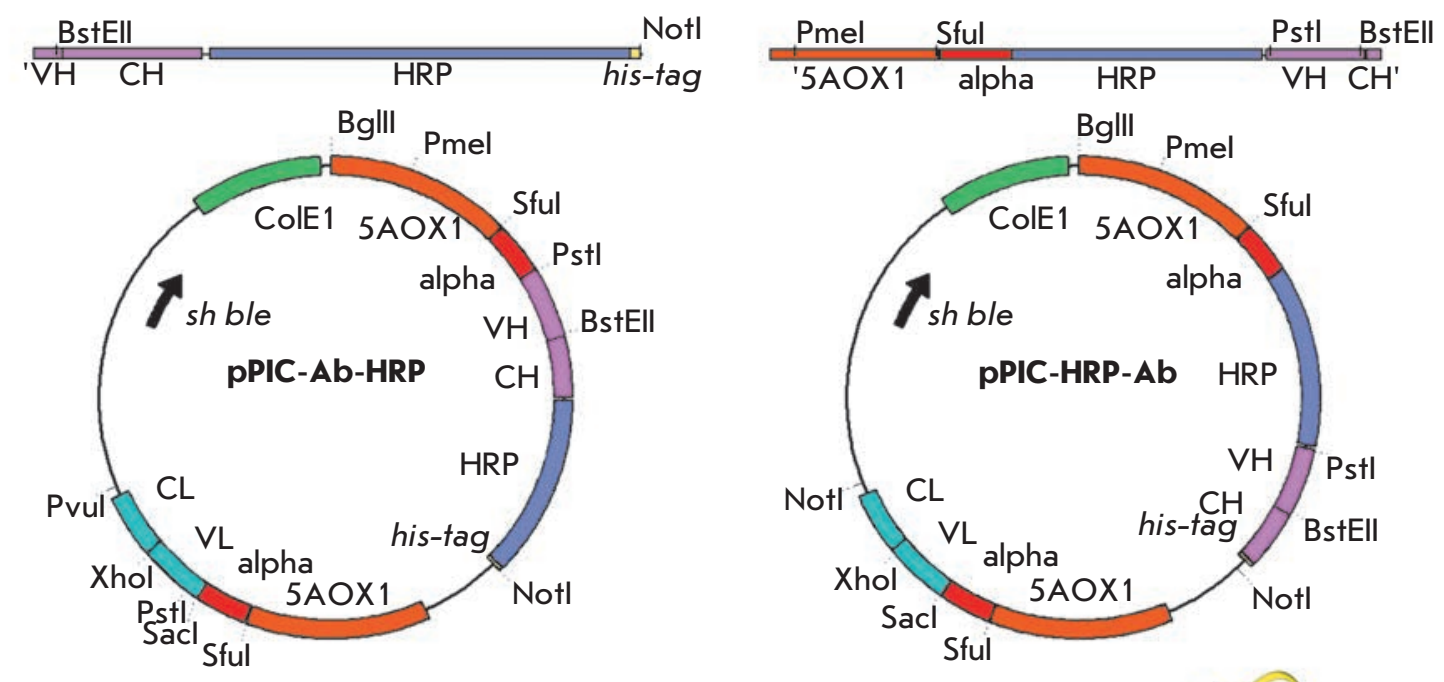

Fig. 2. General versatile expression vectors for recombinant conjugates of HRP with Fab antibody fragments production. The spatial models of recombinant conjugates of Fab-HRP and HRP-Fab are shown in the left and right panels,

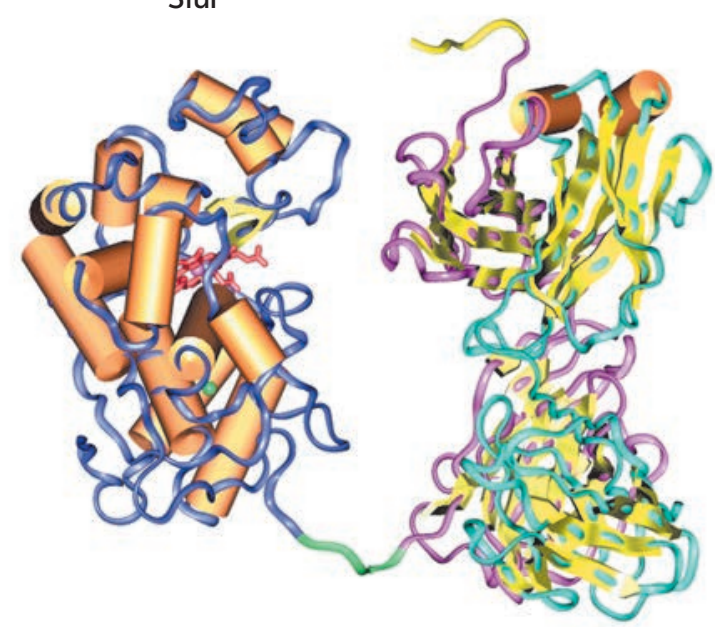
respectively.

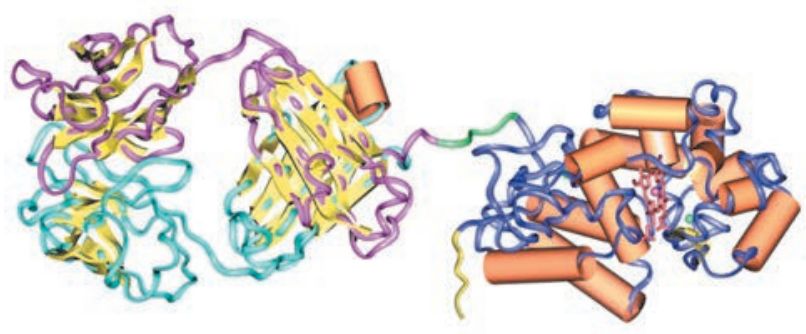


nonfunctional dimers of the light chain, genetic constructions were cloned in the PPIC-Fab vector at the sites PmeI/BstEII and BstEII/NotI, respectively; the heavy chain was selected for the cloning of the marker protein gene. The mutual arrangement of genes in plasmids pPIC-Ab-HRP and pPIC-HRP-Ab was confirmed by restriction analysis and sequencing.

Expression and purification of recombinant conjugates Fab-HRP and HRP-Fab $P$. pastoris $\mathrm{X} 33$ cells (Invitrogen) were transformed via the plasmid vectors $\mathrm{pPIC}-\mathrm{Ab}-\mathrm{HRP}$ and $\mathrm{pPIC}-\mathrm{HRP}-\mathrm{Ab}$ using electroporation with an efficiency of approximately 100 clones per $10 \mu \mathrm{g}$ of plasmid DNA. The expression of the target protein was tracked by increasing the peroxidase activity in the supernatant of the culture medium, reaching a plateau on day 5 of cultivation. Ten clones were analyzed with each construction. The HRP activity with respect to the TMB substrate was detected only in three clones out of 20 : two clones $(1.1,1.2)$ corresponding to $\mathrm{pPIC}-\mathrm{Ab}-\mathrm{HRP}$ and one clone (8) corresponding to pPIC-HRP-Ab. These clones were selected for further consideration.

As shown by SDS-PAGE electrophoresis (the data are not provided), the blurred bands located below the band at $100 \mathrm{kDa}$ correspond to the recombinant conjugates $\mathrm{HRP}-\mathrm{VCH}$ and $\mathrm{VCH}-\mathrm{HRP}$. This blurriness of the bands is accounted for by the microheterogeneity of conjugates, conditioned by excessive glycosylation that is typical for P. pastoris; correlating with our data and the data published on the expression of the HRP gene [9]. A considerably greater excess (by a factor of 3-4) of light-chain molecules was observed (the band at $25 \mathrm{kDa}$ ) in comparison with that found during the expression of the Fab fragment [19]. Unexpectedly, it occurred that the recombinant conjugated manifested no enzymatic activity toward another peroxidase substrate, ABTS, as opposed to TMB. It is well known that the site of binding with ABTS is located in the hydrophobic region on the HRP surface, in the so-called "Phe patch" zone [25]. This zone is noticeably distant from the active site of HRP, and it can be assumed that the substrate binding to it is complicated due to steric reasons - as a result of excessive glycosylation or the presence of a Fab fragment of antibody. The first hypothesis is more probable, since the same effect is observed under both positions of the heavy chain of the antibody with respect to HRP. Moreover, a similar effect was earlier observed upon expression of the HRP gene in P. pastoris (the data have not been published).

The total yield of recombinant conjugates was approximately 3-10 mg per 11 of the $P$. pastoris culture supernatant. A relatively low yield of secreted conjugates correlates with the yield upon expression of

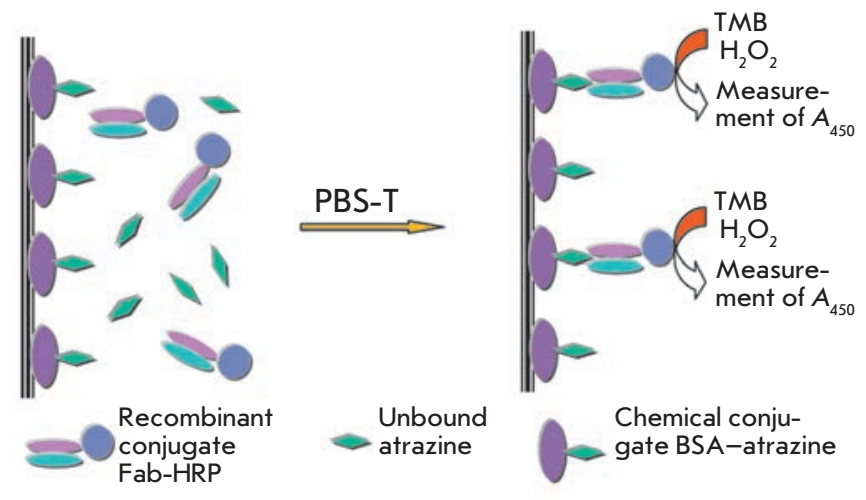

Fig. 3. ELISA scheme for atrazine determination.

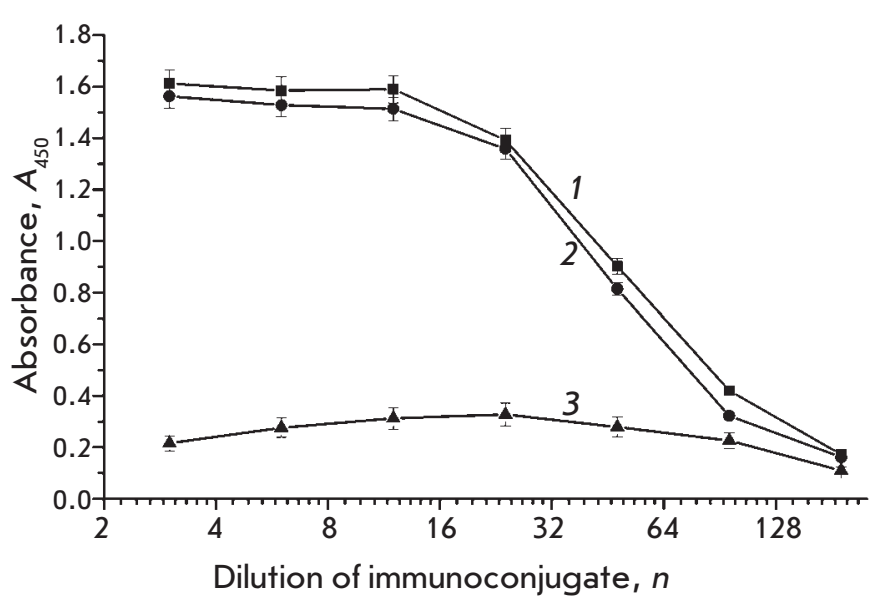

Fig. 4. Titration of recombinant conjugates: $1-$ FabHRP (clone 1.1); 2 - Fab-HRP (clone 1.2); 3 - HRP-Fab (clone 8).

the HRP gene only. We believe that one of the factors that have a negative effect on the yield of the secreted product is the excessive glycosylation of the peroxidase component of the conjugate, which is typical of $P$. pastoris cells. In order to verify this hypothesis, it may be reasonable to remove all $\mathrm{N}$-glycosylation sites in HRP or replace HRP with another reporter protein, such as EGFP.

\section{Characterization of recombinant \\ conjugates by ELISA}

In order to confirm the antigen-binding activity of recombinant conjugates, we selected the scheme of indirect competitive single-stage ELISA (Fig. 3) carried out on the wells with an immobilized atrazine-BSA conjugate. The binding of recombinant conjugates to atrazine was preliminarily studied (Fig. 4). The data obtained attest to the presence of both catalytic and antibody 


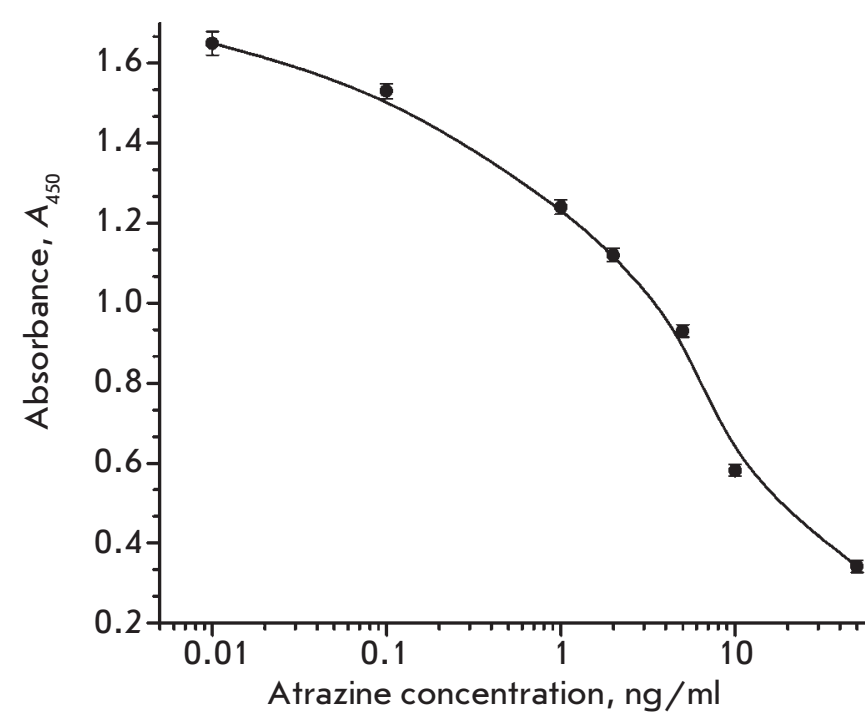

Fig. 5. Calibration curve for atrazine determination in competitive ELISA with recombinant conjugate of Fab-HRP (clone 1.1).

activity in all three clones. However, the low activity of the HRP-Fab sample (clone 8) in comparison with the $\mathrm{C}$-terminal conjugate Fab-HRP (clones 1.1 and 1.2) may attest to the fact that the mutual spatial arrangement of two components of the chimeric protein in this case results in a decrease in the catalytic activity of peroxidase. The samples of recombinant conjugates Fab-HRP (clones 1.1 and 1.2) have similar characteristics, and specimen 1.1 was used for further ELISA determination of atrazine. The typical calibration diagram (Fig. 5) allows one to determine the atrazine concentration over a wide range, from 0.1 to $50 \mathrm{ng} / \mathrm{ml}$; the variation coef- ficient being no higher than $8 \% . \mathrm{IC}_{50}$ is equal to $3 \mathrm{ng} / \mathrm{ml}$, which agrees well with the results of atrazine determination by a two-stage ELISA procedure using recombinant Fab fragments of the same antibody K411B [19] and with the data on the single-chain mini-antibody ( $\mathrm{scFv}$ ) obtained earlier in E. coli [24]. Meanwhile, in the initial monoclonal antibody, the $\mathrm{IC}_{50}$ value was equal to $0.2 \mathrm{ng} / \mathrm{ml}$ [19]. As is evident in the majority of similar cases, the fact that the $\mathrm{IC}_{50}$ value differs from that of recombinant antibodies is in all likelihood connected with the bivalence of the initial monoclonal antibody.

Thus, the recombinant conjugates of peroxidase with Fab fragments of antibody against atrazine obtained in the present study possess functional activity and can be used to determine atrazine via ELISA.

\section{CONCLUSIONS}

The possibility of using a recombinant, functionally active HRP (as a marker enzyme) conjugated with Fab fragments of the antibody against atrazine was shown for the first time. In the present study, recombinant conjugates were obtained in which the Fab fragment of an antibody is bound both to the $\mathrm{N}$ - and the $\mathrm{C}$ - terminuses of the marker enzyme. Both these variants manifest immunological and catalytic activity.

The functional secretion of recombinant conjugates of HRP with Fab fragments of antibodies offers opportunities for broad application in ELISA. The results obtained will be used to design highly sensitive immunobiosensors of a new generation, based on the recombinant DNA technology.

The study was partially supported by the German Federal Ministry of Science and Technology (BMBF, grant № 0311574).

\section{REFERENCES}

1. Rau D., Kramer K., Hock B. // J. Immunoassay Immunochem. 2002. V. 23. № 2. P. 129-143.

2. Tachibana H., Takekoshi M., Cheng X.J., Nakata Y., Takeuchi T., Ihara S. // Clin. Diagn. Lab. Immunol. 2004. V. 11. №1. P. 216-218.

3. Mousli M., Turki I., Kharmachi H., Saadi M., Dellagi K. // J. Virol. Meth. 2007. V. 146. №1-2. P. 246-256.

4. Patel K.G., Ng P.P., Kuo C.C., Levy S., Levy R., Swartz J.R. // Biochem. Biophys. Res. Commun. 2009. V. 390. № 3. P. 971-976.

5. Joosten V., Roelofs M.S., van den Dries N., Goosen T., Verrips C.T., van den Hondel C.A., Lokman B.C. // J. Biotechnol. 2005. V. 120. № 4. P. 347-359.

6. Grigorenko V., Andreeva I., Borchers T., Spener F., Egorov A. // Anal. Chem. 2001. V. 73. № 6. P. 1134-1139.

7. Robin S., Petrov K., Dintinger T., Kujumdzieva A., Tellier C., Dion M. // Mol. Immunol. 2003. V. 39. № 12. P. 729-738.
8. Cupit P.M., Whyte J.A., Porter A.J., Browne M.J., Holmes S.D., Harris W.J., Cunningham C. // Lett. Appl. Microbiol. 1999. V. 29. № 5. P. 273-277.

9. Morawski B., Lin Z., Cirino P., Joo H., Bandara G., Arnold F.H. // Protein Eng. 2000. V. 13. № 5. P. 377-384.

10. Pennell C.A., Eldin P. // Res. Immunol. 1998. V. 149. № 6. P. 599-603.

11. Fischer R., Drossard J., Emans N., Commandeur U., Hellwig S. // Biotechnol. Appl. Biochem. 1999. V. 30. Pt 2. P. $117-112$.

12. Freyre F.M., Vazquez J.E., Ayala M., Canaan-Haden L., Bell H., Rodriguez I., Gonzalez A., Cintado A., Gavilondo J.V. // J. Biotechnol. 2000. V. 76. № 2-3. P. 157-163.

13. Takahashi K., Yuuki T., Takai T., Ra C., Okumura K., Yokota T., Okumura Y. // Biosci. Biotechnol. Biochem. 2000. V. 64. № 10. P. 2138-2144.

14. Andrade E.V., Albuquerque F.C., Moraes L.M., Brigido M.M., Santos-Silva M.A. // J. Biochem. (Tokyo.) 2000. V. 128. 


\section{RESEARCH ARTICLES}

№ 6. P. 891-895.

15. Luo D., Geng M., Schultes B., Ma J., Xu D.Z., Hamza N., Qi W., Noujaim A.A., Madiyalakan R. // J. Biotechnol. 1998. V. 65. № 2-3. P. 225-228.

16. Powers D.B., Amersdorfer P., Poul M., Nielsen U.B., Shalaby M.R., Adams G.P., Weiner L.M., Marks J.D. // J. Immunol. Meth. 2001. V. 251. № 1-2. P. 123-135.

17. Hellwig S., Emde F., Raven N.P., Henke M., van der Logt P., Fischer R. // Biotechnol. Bioeng. 2001. V. 74. № 4. P. 344-352.

18. Sambrook J., Fritsch E.F., Maniatis T. Molecular Cloning: A Laboratory Manual. Cold Spring Harbor, N.Y.; Cold Spring Harbor Lab. Press, 1989.

19. Lange S., Schmitt J., Schmid R.D. // J. Immunol. Meth. 2001. V. 255. P. 103-114.
20. Giersch T. // J. Agric. Food Chem. 1993. V. 41. № 6.

P. 1006-1011.

21. Braman J., Papworth C., Greener A. // Methods Mol. Biol. 1996. V. 57. P. 31-44.

22. Grigorenko V., Chubar T., Kapeliuch Yu., Borchers T., Spener F., Egorov A. // Biocatal. Biotransform. 1999. V. 17. P. 359-397.

23. Ferrari R.P., Traversa S., de Gioia L., Fantucci P., Suriano G., Ghibaudi E.M. // J. Biol. Inorg. Chem. 1999. V. 4. № 1. P. $12-20$.

24. Kramer K., Hock B. // Food Agric. Immunol. 1996. V. 8. P. 97-109. 